\title{
PELATIHAN PENGGUNAAN JEJARING SOSIAL INSTAGRAM DALAM MEMASARKAN BARANG PADA IBU-IBU PKK DI KELURAHAN RAWAMANGUN JAKARTA TIMUR
}

\author{
Ika Febrilia' ${ }^{1)}$, Hafifah Nasution ${ }^{2)}$, Dwi Handarini ${ }^{3)}$ \\ Fakultas Ekonomi, Universitas Negeri Jakarta \\ E-mail: ikafebrilia.bj@gmail.com ${ }^{1)}$, hafifahnst@gmail.com²),dwihandarini@gmail.com³)
}

\begin{abstract}
Along with the development of the times, human needs for information and the use of technology (internet) is growing rapidly. By using the internet, especially social networks, people of all ages, gender, social class, economy and culture can know the various developments that occur in their environment and can interact with each other without being limited by space and time. Currently, Instagram has become one of the most widespread social networking categories used by most people in Indonesia to introduce and promote their products. Instagram is believed to be not only beneficial for online shop, retailer, restaurant, travel company, and e-commerce, but also one of the most effective tools in building a business brand. In fact, Instagram is also not only in demand by men and women who are young entrepreneurs, but also housewives who have passion in developing business from home (home business). The activity (Pengabdian Masyarakat) that was held on Tuesday, October 3, 2017 is basically done to socialize the use of Instagram as social networking among PKK (Pembinaan Kesejahteraan Keluarga) mothers in Rawamangun, East Jakarta. Training is done by using classical method for 1.5 hours in the form of Instagram account creation, delivery of core material by expert speakers, and sharing experiences to motivate mothers to become mompreneur.
\end{abstract}

Keywords: Social Network, Instagram, Entrepreneurship, East Jakarta

\begin{abstract}
ABSTRAK
Seiring dengan perkembangan zaman, kebutuhan manusia akan informasi dan penggunaan teknologi (internet) semakin berkembang pesat. Dengan menggunakan internet, terutama jejaring sosial, masyarakat dari berbagai kalangan usia, gender, kelas sosial, ekonomi dan budaya dapat mengetahui berbagai perkembangan yang terjadi di lingkungan sekitar mereka serta dapat berinteraksi satu sama lain tanpa dibatasi oleh ruang dan waktu. Saat ini, Instagram telah menjadi salah satu kategori jejaring sosial yang marak digunakan oleh sebagian besar masyarakat di Indonesia untuk memperkenalkan dan mempromosikan produk mereka. Instagram diyakini tidak hanya bermanfaat bagi online shop, retailer, restaurant, perusahaan travel, dan e-commerce saja, tetapi juga menjadi salah satu alat yang paling efektif dalam membangun sebuah brand bisnis. Faktanya, Instagram juga tidak hanya diminati oleh pria dan wanita yang merupakan para entrepreneur muda, namun juga ibu-ibu rumah tangga yang memiliki passion dalam mengembangkan usaha dari rumah (bisnis rumahan). Kegiatan Pengabdian Masyarakat yang telah diadakan pada hari Selasa, tanggal 3 Oktober 2017 ini pada dasarnya dilakukan untuk mensosialisasikan penggunaan jejaring sosial Instagram di kalangan ibu-ibu PKK (Pembinaan Kesejahteraan Keluarga) di Kelurahan Rawamangun, Jakarta Timur. Pelatihan dilakukan dengan menggunakan metode klasikal selama 1,5 jam berupa pembuatan account Instagram, penyampaian materi inti oleh narasumber ahli, dan sharing pengalaman untuk semakin memotivasi ibu-ibu menjadi mompreneur.
\end{abstract}

Kata kunci: Jejaring Sosial, Instagram, Kewirausahaan, Jakarta Timur

\section{PENDAHULUAN}

Seiring dengan perkembangan zaman, kebutuhan manusia akan informasi dan teknologi semakin berkembang pesat (Suciseptia, 2014). Salah satu teknologi yang memungkinkan setiap orang dapat mengakses informasi dalam kehidupan sehari-hari adalah internet. Dengan menggunakan internet, masyarakat dari berbagai kalangan usia, gender, kelas sosial, ekonomi dan budaya dapat mengetahui berbagai perkembangan yang terjadi di lingkungan sekitar mereka serta dapat berinteraksi satu sama lain tanpa dibatasi oleh ruang dan waktu, yaitu salah satunya dengan memanfaatkan jejaring sosial (Rismayeti, 2011).

Istilah jejaring sosial untuk pertama kalinya dikenalkan oleh Professor J.A Barnes (1954). Jejaring sosial diartikan sebagai sebuah sistem struktur sosial yang terdiri dari elemen-elemen individu atau organisasi. Jejaring sosial merupakan sebuah struktur

Jurnal Sarwahita Vol. 14 No. 02 Tahun 2017 | 108 
sosial atau tatanan sosial dimana individu ataupun organisasi yang terlibat di dalamnya memiliki hubungan yang spesifik. Dengan adanya jejaring sosial, manusia dengan kesamaan sosialitas dapat saling berhubungan. Berdasarkan pengertian jejaring sosial tersebut ada satu hal yang penting yang harus ada dalam sebuah struktur sosial pada berbagai jaringan sosial, yaitu individu atau organisasi yang saling berhubungan, dan ada tujuan tertentu dalam hubungan tersebut (Joel, 2015).

Jejaring sosial memungkinkan orangorang dari seluruh dunia untuk berbagi teks, gambar, audio dan informasi melalui video, bahkan menjadi media bagi seorang marketer dalam mempromosikan, membangun image hingga menjual produknya. Jejaring sosial dapat digunakan untuk membangun komunitas bagi para pengguna produk atau layanan dengan tujuan untuk membangun hubungan dan menciptakan komunikasi dua arah, sehingga marketer dapat mendengar dan mengetahui langsung apa yang menjadi kebutuhan dan keinginan para konsumennya (Gondokusumo, 2016).

Saat ini, Instagram telah menjadi salah satu kategori jejaring sosial yang marak digunakan oleh sebagian besar masyarakat di Indonesia untuk memperkenalkan dan mempromosikan produk mereka. Hal ini mengingat bahwa pada tahun 2016, pengguna aktif di Instagram telah mencapai 500 juta orang, dengan 95 juta foto atau video yang diunggah setiap harinya (Gondokusumo, 2016). Selain itu, berdasarkan data dari kominfo.go.id (2016), Instagram diklaim lebih populer dibandingkan Twitter, memiliki berjuta-juta pengguna aktif, dengan pengguna yang sebagian besar memanfaatkan menumenu dalam aplikasi ini untuk mencari informasi produk online shop, meme, dan mengunggah foto-foto liburan dan wisata.

Dari angka tersebut, tidak mengherankan apabila banyak orang yang tertarik untuk menjadikan Instagram sebagai salah satu strategi pemasaran yang efektif dalam mencapai target dan menjangkau pasar, atau dikenal dengan istilah instagram marketing 109| Jurnal Sarwahita Vol. 14 No. 02 Tahun 2017
(Gondokusumo, 2016). Instagram diyakini tidak hanya bermanfaat bagi online shop, retailer, restaurant, perusahaan travel, dan ecommerce saja, tetapi juga menjadi salah satu alat yang paling efektif dalam membangun sebuah brand bisnis (Mayuda, 2016). Faktanya, Instagram juga tidak hanya diminati oleh pria dan wanita yang merupakan para entrepreneur muda, namun juga ibu-ibu rumah tangga yang memiliki passion dalam mengembangkan usaha dari rumah (bisnis rumahan) (Dahlan, 2016).

Ibu-ibu tersebut biasanya akan terpikir untuk membuka usaha sendiri, yang memungkinkan mereka untuk bekerja mendapatkan penghasilan tambahan sambil sekaligus mengurus keluarga. Mereka dapat menjalankan usaha kerajinan tangan, membuka catering, berjualan produk fashion dan alat-alat rumah tangga secara online, event organizer untuk pesta ulang tahun anak, usaha make-up artist, hingga menjadi guru les (Wahyuni, 2017).

Berdasarkan uraian tersebut di atas, maka dalam kegiatan Pengabdian Masyarakat kali ini, pelaksana ingin mensosialisasikan pemanfaatan jejaring sosial terutama Instagram dalam mempromosikan barang, dengan sasaran ibu-ibu PKK di Kelurahan Rawamangun, Jakarta Timur. Dengan pelatihan ini, diharapkan bahwa ibu-ibu PKK yang sebagian besar merupakan ibu-ibu Rumah Tangga dapat lebih familiar dalam menggunakan Instagram, serta dapat memberikan inspirasi kepada ibu-ibu tersebut untuk membangun bisnis/usaha kecil-kecilan secara online.

Adapun rumusan masalah yang ada dalam kegiatan ini, yaitu sebagai berikut: 1) apakah ibu-ibu PKK di Kelurahan Rawamangun, Jakarta Timut telah familiar dalam menggunakan jejaring sosial Instagram dalam kehidupan sehari-hari?; 2) bagaimana teknik dalam memasarkan barang melalui jejaring sosial, bagi ibu-ibu PKK di Kelurahan Rawamangun yang sudah memiliki usaha/bisnis?; 3) apakah kegiatan pelatihan juga dapat memberikan inspirasi mengenai peluang bisnis yang dapat dilakukan dengan 
memanfaatkan jejaring sosial, bagi ibu-ibu PKK di Kelurahan Rawamangun yang belum memiliki usaha/bisnis? Sedangkan tujuan diadakannya kegiatan Pengabdian Masyarakat ini, yaitu: 1) memberikan pengenalan kepada ibu-ibu PKK di Kelurahan Rawamangun tentang jejaring sosial Instagram serta tata cara penggunaannya dalam kehidupan seharihari; 2) memberikan bimbingan dan konsultasi mengenai manfaat jejaring sosial Instagram sebagai sarana memasarkan ataupun mempromosikan barang; dan 3) memberikan pengetahuan dan semangat kewirausahaan, sehingga ibu-ibu PKK yang tidak bekerja (Ibu Rumah Tangga) dapat memanfaatkan jejaring sosial Instagram untuk membantu meningkatkan ekonomi keluarga.

Selain itu, kegiatan ini diharapkan dapat memberikan manfaat, yaitu yang terkait dengan: 1) ibu-ibu PKK di Kelurahan Rawamangun memiliki pengetahuan praktis dan sederhana mengenai jejaring sosial terutama Instagram serta tata cara penggunaannya; 2) menambah pengetahuan sekaligus memberikan perspektif lain mengenai teknik yang dapat digunakan dalam memasarkan barang untuk tujuan bisnis; 3) menumbuhkan semangat bagi ibu-ibu dalam mengeksplor pengetahuan maupun keahlian yang selama ini dimiliki tapi belum dimanfaatkan atau hanya diaplikasikan di lingkungan rumah tangga saja. Minat berwirausaha ibu-ibu diharapkan dapat tumbuh, mengoptimalkan waktu yang dimiliki sebagai Ibu Rumah Tangga dengan mencoba memasarkan ataupun mempromosikan barang menggunakan jejaring sosial Instagram, untuk membantu meningkatkan ekonomi keluarga.

\section{METODE PELAKSANAAN}

Kegiatan Pengabdian Masyarakat ini pada dasarnya dilakukan untuk mensosialisasikan penggunaan jejaring sosial Instagram di kalangan ibu-ibu PKK di Kelurahan Rawamangun, Jakarta Timur. Tidak hanya itu, kegiatan ini juga berupaya untuk mengarahkan ibu-ibu PKK yang sebagian besar merupakan ibu rumah tangga pada usaha/bisnis online yang dapat dilakukan dari rumah. Dengan pelatihan yang berfokus pada tata cara memasarkan barang melalui jejaring sosial, diharapkan bahwa kegiatan ini dapat memberikan inspirasi dan masukan kepada ibu-ibu untuk berpikir kreatif, baik itu menciptakan sendiri barang yang ingin dipasarkan (eksplorasi diri) maupun mengupayakan peluang untuk menjadi reseller.

Adapun kerangka atau tahapan yang dilakukan dalam Pelatihan Penggunaan Jejaring Sosial Instagram dalam Memasarkan Barang pada Ibu-Ibu PKK di Kelurahan Rawamangun, Jakarta Timur mencakup analisis kebutuhan, yaitu: a) masih banyak ibu-ibu PKK yang belum bisa mengoperasionalkan aplikasi jejaring sosial Instagram dalam kehidupan sehari-hari. Umumnya, ibu-ibu tersebut hanya menggunakan aplikasi seperti Facebook, WhatsApp Messanger maupun Line yang digunakan hanya untuk tujuan berkomunikasi; b) ada beberapa ibu-ibu PKK yang sudah memiliki usaha/bisnis rumahan, namun mereka masih menjalankan usaha mereka tersebut secara konvensional, dan membutuhkan metode lain (terutama metode memasarkan melalui internet) untuk semakin meningkatkan daya saing usahanya; c) ibu-ibu PKK yang mengalami kondisi di atas (poin b) sangat membutuhkan pengetahuan mengenai tata cara pemanfaatan jejaring sosial Instagram untuk mendukung bisnis, misalnya dalam membuat bio/profil account Instagram mereka (home), mem-posting foto dan menulis caption yang menarik bagi barang yang ingin dijual, merespon dan berinteraksi dengan calon konsumen melalui photo comments dan direct message, dan sebagainya.

Tahapan yang kedua merupakan rancangan instruksional dengan mempertimbangkan aspek isi materi program pelatihan yang dibuat relevan dengan kebutuhan peserta. Sesuai dengan analisis kebutuhan yang telah dijelaskan sebelumnya, tim pelaksana melakukan pemetaan materi, yang dibagi menjadi: a) materi yang berisi tentang tata cara pembuatan account Jurnal Sarwahita Vol. 14 No. 02 Tahun 2017 | 110 
Instagram; dan b) pemanfaatan Instagram dalam mempromosikan dan menjual barang. Tahapan yang terakhir merupakan tahap pengembangan yang berupaya membangun pelatihan dengan tidak hanya mempresentasikan tahapan-tahapan dalam pembuatan account Instagram maupun metode-metode yang dapat dilakukan dalam memanfaatkan Instagram untuk kepentingan bisnis. Tim pelaksana berusaha mendatangkan narasumber yang merupakan seorang entrepreneur muda yang telah sukses dalam menjalankan bisnis melalui jejaring sosial Instagram. Tim pelaksana berharap bahwa ibu-ibu PKK tidak sekedar mendengarkan materi saja selama pelatihan, namun juga dapat langsung berkonsultasi dan memetik pelajaran dari sharing pengalaman yang dikemukakan oleh narasumber.

Pemecahan masalah dilakukan dalam berbagai tahapan, yang meliputi: a) melakukan koordinasi dengan Kantor Kelurahan dan PKK Rawamangun, guna menganalisis kebutuhan dan memastikan kemungkinan tim pelaksana untuk mengadakan kegiatan bersama-sama dengan ibu-ibu PKK, sekaligus menentukan waktu dan lamanya pelaksanaan kegiatan; b) melakukan identifikasi dan recruitment peserta; dan c) menghubungi beberapa pihak yang dianggap dapat menjadi narasumber ahli, hingga akhirnya mendapatkan konfirmasi dari Shandy Aditya yang merupakan seorang entrepreneur muda yang telah aktif dalam menjalankan bisnis melalui jejaring sosial Instagram.

Kegiatan pengabdian masyarakat telah dilaksanakan pada hari Selasa, tanggal 3 Oktober 2017, mulai dari pukul 14.00 hingga pukul 15.30 WIB, dihadiri oleh 30 peserta. Peserta pada pelatihan ini terdiri dari para pengurus PKK, dan ibu-ibu anggota PKK yang mewakili setiap RT yang ada di Kelurahan Rawamangun, Jakarta Timur. Sedangkan untuk evaluasi dilakukan dengan melihat indikator pencapaian sebagai berikut: a) seluruh peserta pelatihan yang merupakan ibu-ibu PKK telah memiliki account Instagram dan memahami menu-menu yang 111 | Jurnal Sarwahita Vol. 14 No. 02 Tahun 2017 ada pada jejaring sosial Instagram tersebut, beserta tata cara penggunaannya; b) ibu-ibu PKK memahami teknik yang dapat digunakan jika mereka ingin mulai mencoba untuk mempromosikan dan/atau memasarkan barang melalui jejaring sosial Instagram; dan c) ibu-ibu PKK yang belum memiliki usaha mulai mengeksplor berbagai kemungkinan usaha yang dapat mereka lakukan, untuk selanjutnya dipasarkan melalui jejaring sosial Instagram.

Sasaran kegiatan sosialisasi pemanfaatan jejaring sosial Instagram dalam mempromosikan barang adalah ibu-ibu PKK di Kelurahan Rawamangun Jakarta Timur. Ibu-ibu PKK yang dimaksud merupakan ibu rumah tangga (wanita yang tidak bekerja) dengan tingkat ekonomi keluarga yang bervariasi (menengah hingga menengah ke bawah). Ibu-ibu PKK ini adalah para Ibu yang aktif bersosialisasi dan masih menyempatkan waktu untuk mengikuti berbagai kegiatan di lingkungan PKK, di tengah kesibukan mengurus rumah tangga. Mereka biasanya berkumpul untuk menghadiri berbagai kegiatan yang dikoordinasi oleh Kantor Kelurahan Jakarta Timur. Dari situasi kondisi tersebut, maka ibu-ibu PKK di Kelurahan Rawamangun Jakarta Timur dianggap relevan sebagai sasaran dalam kegiatan ini.

Pelatihan akan dilakukan menggunakan metode klasikal, yaitu narasumber akan menjelaskan sekaligus membuat simulasi berupa tata cara pembuatan account Instagram selama 30 menit, yang dilanjutkan dengan penyampaian materi inti berupa teknik-teknik yang bisa digunakan ibu-ibu dalam memanfaatkan jejaring sosial Instagram untuk keperluan bisnis, selama 30 menit. Selanjutnya, pada 30 menit terakhir akan dilakukan diskusi dan sharing pengalaman antara narasumber ahli dengan ibu-ibu mengenai pengetahuan maupun keahlian yang dimiliki ibu-ibu PKK yang mungkin selama ini belum dapat dieksplor secara lebih mendalam dikarenakan kesibukan rumah tangga, yang dapat semakin dikembangkan dalam bentuk sebuah bisnis yang akan dipasarkan secara online melalui Instagram. 


\section{HASIL DAN PEMBAHASAN}

Kegiatan pengabdian masyarakat berupa pelatihan penggunaan jejaring sosial Instagram dalam memasarkan barang pada ibu-ibu PKK di Kelurahan Rawamangun, Jakarta Timur, telah menghasilkan beberapa hal sebagai berikut:

a. Berdasarkan hasil analisis kebutuhan yang telah dilakukan oleh tim pelaksana sebelum kegiatan pengabdian masyarakat dilakukan, ditemukan bahwa masih banyak ibu-ibu PKK di Kelurahan Rawamangun, Jakarta Timur yang belum memiliki account Instagram dan belum familiar dalam menggunakan menu-menu yang ada pada aplikasi Instagram.

b. Tim pelaksana juga menemukan bahwa ada beberapa ibu PKK yang telah memiliki bisnis namun masih menjalankannya dengan cara konvensional. Namun, ibu-ibu PKK tersebut menjadi sangat antusias jika ada pihak dan/atau narasumber ahli yang dapat berbagi pengalaman dalam menjalankan bisnis secara online, sehingga mereka dapat semakin mengembangkan usahanya.

Pada kegiatan pengabdian masyarakat, penyampaian materi oleh narasumber diawali dengan simulasi mengenai cara pembuatan account Instagram beserta penjelasan lengkap tentang fungsi menu-menu yang ada pada Instagram. Para ibu PKK di Kelurahan Rawamangun yang sudah memiliki bisnis juga mendapatkan pengetahuan mengenai teknik/metode dalam memasarkan barang secara online, mulai dari membuat bio/profil account Instagram mereka (home), memposting foto dan menulis caption yang menarik bagi barang yang ingin dijual, merespon dan berinteraksi dengan calon konsumen melalui photo comments dan direct message, dan sebagainya. Bagi ibu-ibu PKK yang belum memiliki bisnis sampingan, dengan adanya kegiatan pelatihan ini pada akhirnya memotivasi mereka untuk mencari peluang usaha yang juga dapat dipasarkan melalui jejaring sosial, terutama Instagram.

\section{PENUTUP}

Kegiatan pengabdian masyarakat ini menghasilkan beberapa kesimpulan sebagai berikut:

a. Kegiatan pelatihan ini merupakan tindak lanjut dari semakin berkembangnya teknologi dan pemanfaatan berbagai jejaring sosial dalam mempromosikan dan memasarkan barang dalam dunia bisnis.

b. Pemanfaatan jejaring sosial Instagram untuk kepentingan bisnis ini juga disosialisasikan pada ibu-ibu PKK di Kelurahan Rawamangun, Jakarta Timur dengan tujuan agar ibu-ibu tersebut dapat terinspirasi untuk menjadi seorang mompreneur, mengeksplor kemampuan yang dimiliki, mampu menjalankan usaha/bisnis rumahan secara online demi semakin meningkatkan ekonomi keluarganya.

Adapun saran yang dapat diberikan oleh tim pelaksana demi peningkatan kualitas kegiatan pelatihan di masa yang akan datang, meliputi:

a. Mengadakan monitoring pasca pelatihan untuk melihat progress dari kegiatan yang telah dilakukan, yaitu apakah ibu-ibu PKK benar-benar telah berhasil dalam memanfaatkan jejaring sosial Instagram dalam memasarkan barang.

$b$. Melakukan pelatihan serupa dengan target ibu-ibu PKK maupun ibu-ibu rumah tangga di kawasan lainnya di Jakarta, guna semakin meningkatkan kemungkinan terciptanya mompreneur.

Melibatkan entrepreneur muda lainnya, terutama dari kalangan wanita atau ibu-ibu untuk semakin menambah motivasi para ibu PKK dalam menjalankan bisnis.

\section{DAFTAR PUSTAKA}

Aditia R. 2015. Sejarah dan Perkembangan Aplikasi Sosial Media Instagram. Tersedia pada: http://www.gudangilmukomputer.com /2015/12/sejarah-dan-perkembanganaplikasi-sosial-media-instagram.html 
Chaffey D, Mayer R, Johnston K, EllisChadwick F. 2000. Internet Marketing: Strategy, Implementation, and Practice. London: Pearson Education Limited.

Dahlan D. 2016. Mompreneur! Usaha Sampingan untuk Ibu Rumah Tangga. Tersedia pada: http://www.dedydahlan.com/blog/mo mpreneur-usaha-sampingan-untukibu-rumah-tangga/

Gondokusumo R. 2016. Cara Beriklan di Instagram untuk Meningkatkan Pemasaran Bisnis Online Anda. Tersedia pada: http://blog.sribu.com/cara-beriklan-diinstagram/

Gondokusumo R. 2016. 4 Manfaat Media Sosial untuk Program Digital Marketing Bisnis Anda. Tersedia pada: http://blog.sribu.com/socialmedia-digital-marketing/

Hidayat A.A.N. 2017. 45 Juta Pengguna Instagram, Indonesia Pasar Terbesar di Asia. Tersedia pada: https://bisnis.tempo.co/read/894605/4 5-juta-pengguna-instagram-indonesiapasar-terbesar-di-asia

Joel B. 2015. Pengertian Jejaring Sosial dan Macam-Macam Jejaring Sosial. Tersedia pada: https://www.idjoel.com/pengertianjejaring-sosial-dan-macam-macamjejaring-sosial/

Kurniawan H. 2015. Efektivitas Media Sosial Instagram sebagai Media Promosi Batik Solo "INASINUL". Skripsi Institut Pertanian Bogor.

Mayuda A. 2016. Ingin Berbisnis Online? Inilah 11 Cara Sukses Menggunakan Instagram untuk Bisnis Anda. Tersedia pada: http://blog.sribu.com/caramenggunakan-instagram-untukbisnis/

Orcatti. 2012. Pengaruh Peran Media Sosial Twitter terhadap Brand Awareness Produk Buffalo. Studi Kasus: PT ECS Indo Jaya. Jakarta: Universitas Bina Nusantara.
Rahmawati D. 2016. Pemilihan dan Pemanfaatan Instagram sebagai Media Komunikasi Pemasaran Online. Skripsi Universitas Islam Negeri Sunan Kalijaga Yogyakarta.

Rismayeti. 2011. Manfaat Internet dalam Jejaring Sosial. Tersedia pada: https://rismayeti.wordpress.com/2011/ 12/12/manfaat-internet-dalamjejaring-sosial/

Silva S. 2015. Sejarah Asal Mula Media Sosial/Jejaring Sosial Instagram. Tersedia pada: http://satupedang.blogspot.co.id/2015/ 02/sejarah-asal-mula-media-sosialinstagram.html

Suciseptia. 2014. Pengaruh Teknologi terhadap Manusia dalam Bidang Ekonomi, Sosial, Budaya, dan Politik. Tersedia pada: https://suciseptiapratiwi.wordpress.co $\mathrm{m} / 2014 / 10 / 03 /$ pengaruh-teknologiterhadap-manusia-dalam-bidangekonomi-sosial-budaya-dan-politik/ Wahyuni N. D. 2017. 6 Usaha yang Dapat Dijalankan Ibu Rumah Tangga. Tersedia pada: http://bisnis.liputan6.com/read/30876 51/6-usaha-yang-dapat-dijalankanibu-rumah-tangga 